Article

\title{
Shifting Scarcities? The Energy Intensity of Water Supply Alternatives in the Mass Tourist Resort of Benidorm, Spain
}

\author{
Hyerim Yoon ${ }^{1, *(\mathbb{B})}$, David Sauri ${ }^{1}$ and Antonio M. Rico Amorós ${ }^{2}$ (D) \\ 1 Departament de Geografia, Universitat Autònoma de Barcelona, 08193 Cerdanyola del Vallès, Spain; \\ david.sauri@uab.cat \\ 2 Instituto Interuniversitario de Geografía, Universidad de Alicante, 03690 San Vicente del Raspeig, Spain; \\ am.rico@ua.es \\ * Correspondence: Hyerim.Yoon@uab.cat; Tel.: +34-622-926-588
}

Received: 29 January 2018; Accepted: 13 March 2018; Published: 15 March 2018

\begin{abstract}
The energy intensity of water-'energy (electricity)-for-water'-is calculated for Benidorm, a mass tourism resort in the Spanish Mediterranean coast, where the urban water cycle has evolved in response to a series of episodes of water stress. The analysis is based on primary data compiled from various actors involved in the urban water cycle encompassing water extraction, end uses, and wastewater treatment, including tertiary treatment. The results provide one of the first analyses of the relations between energy and water in a mass tourist center, which may be of potential interest for other tourist areas. It is estimated that a total of $109 \mathrm{GWh} /$ year of electricity is required to operate the water cycle of Benidorm. About $4 \%$ of total energy use in Benidorm is dedicated to extracting, transporting, and treating water. The most energy-intensive stage is represented by end uses, which accounts for $20 \%$ of the total energy use in Benidorm when the energy required for water pumping and hot water use is considered. Additionally, energy intensity for water extraction was estimated for normal, wet, and two dry year scenarios. In comparison with the normal scenario, energy intensity is six times larger when desalinated water is incorporated during a dry year, whereas the emergency interbasin water transfer resulted in a more moderate increase in energy intensity. While treated wastewater and emergency water transfers appear to be a more convenient solution in energy terms, the strong impulse given to desalination in Spain is forcing local water authorities towards the use of a resource that is much more energy intensive, although, on the other hand, much less dependent on the vagaries of climate. In light of recent technological and managerial developments, the Benidorm case illuminates the challenges appearing in the analysis of the water-energy nexus, especially the fact that scarcity may be transferred from water to energy.
\end{abstract}

Keywords: water-energy nexus; energy intensity for water; energy (electricity)-for-water; desalination; Benidorm

\section{Introduction}

Water and energy are fundamental to human survival, well-being, and economic and non-economic activities. In water-energy nexus studies, the intrinsic links between the two resources are unraveled and summarized as energy-for-water or electricity-for-water (hereafter energy (electricity)-for-water) — energy requirements for water-and water-for-energy—water requirements for energy [1]. Even though these two resources have been treated separately for a long time, the significance of the nexus between the two is gaining attention due to its impact on resource management. Nexus studies have been largely motivated by deprivation affecting the development of one or the other resource, for example, water scarcity restricting electricity production because 
of the lack of cooling water for thermal power plants [2]. On the other hand, the conservation nexus [3] has focused on synergies for reducing energy use for water provision, or vice versa, as an opportunity to achieve sustainable resource use with the aim of reducing operation costs and carbon dioxide emissions [4]. Previous studies have also targeted the trade-offs between water and energy, whereby solving problems from one resource may cause problems for the other. This article offers primary data on the urban water cycle at the municipal level, which are highly inaccessible in Spain since water and energy supply tend to be managed by private companies in Spain. The energy-for-water is calculated for the mass tourism resort of Benidorm, where water stress is a recurrent problem due to high tourism activity and the semi-arid climate of the region. The study includes the new water supply source contributed by the Muchamiel desalination plant and demonstrates changes in energy intensity for water extraction. In the light of recent technological and managerial developments, the Benidorm case illuminates the challenges of transferring scarcity from water to energy.

Urbanization is a significant factor in the water-energy nexus, as water and energy consumption are highly concentrated in urbanized spaces. Globally, urban areas occupy around $2 \%$ of the land but account for $70 \%$ of energy consumption [5]. Urban water demand increases as cities grow in population. This fact challenges decision-makers and institutions to secure a sufficient quantity and quality of energy and water, as many cities are located in water-stressed areas [6]. However, urban areas may benefit from dense geographical patterns, as these patterns maintain efficiency by lowering the intensity of resource use (i.e., consumption per capita) [7]. For this reason, urban water management focuses not only on improving the existing water supply but also on ensuring adaptive measures to climate change through integrated planning that considers energy intensities of their water systems [6].

It is estimated that energy-for-water accounts for $8 \%$ of global energy demand [8]. Energy is needed throughout the water cycle for pumping, transport, purification, urban supply, and wastewater treatment. It is also needed for the mobilization of alternative water resources, such as rainwater or greywater [9]. Thus, energy-for-water calculations vary significantly depending on how the system boundary is defined $[10,11]$. Previous studies have analyzed the urban water-energy nexus from various scales and directions [11-14] or as single case studies $[2,15,16]$. Some studies have aimed at understanding the whole water cycle [16,17], whereas others have focused on specific stages of this cycle [11]. Previous studies have found the estimation of end use energy (electricity)-for-water difficult, as it depends mainly on the behavior of end users. However, this estimation is gaining importance as significant uses of energy are detected in this stage [10,12,17].

In tourism studies, water and energy are increasingly being recognized as crucial resources that require efficient management [18-23]. Water management often faces challenges in popular destinations because availability does not always match demand. For this reason, the importance of water management at the regional and local scales is emphasized along with the importance for water to become a top priority in political agendas [19]. Furthermore, the hotel sector has been proven a relevant target to encourage water conservation through demand management [23]. Along with water, better energy management is increasingly being sought after to reduce carbon dioxide emissions in the tourism industry as well [20,24-26]. Thus, exploring the case of energy (electricity)-for-water in the area with strong tourism activities would also serve to re-evaluate urban water cycles with high energy intensities as a potential target area to lower carbon dioxide emissions.

Benidorm, one of the largest tourist resorts of the Mediterranean coast, provides an interesting example of water management in an area specialized in mass tourism. The importance of water has been recognized as a key factor for the expansion of tourism in Benidorm, as water shortages due to periodic droughts have jeopardized tourism activities in the past [27]. However, its urban water cycle has rarely been examined in relation to energy intensity. Given their importance in economic, social, and environmental terms, an accurate assessment of water and energy interrelationships appears critical to ensure a more efficient use of both resources in mass tourist centers [28]. 
For many water challenged areas where conventional water resources are scarce or unreliable, desalination is increasingly being adopted as a water supply option. In this regard, Spain is following countries, such as China and the U.S., in expanding desalination to meet water needs. This expansion has called for caution due to the high energy costs required to make seawater drinkable. However, the implicit vision of 'abundance' from a non-depletable water source (the ocean) is accelerating the expansion of desalination [29]. In Spain, the conflicts among regions created by interbasin water transfers, such as that of the Ebro River to the eastern and southeastern areas, has enabled desalination to appear as the main water alternative for the coastal Mediterranean regions. As a result, desalination effectively evaded conflicts over water supply and emerged as a technological fix that allegedly solved water constraints for economic growth, urban expansion, and climatic and hydrologic challenges [30]. Large investments were made, but desalination plants in many cases remained idle as they were built with a strong subordination to failed growth-based planning and little consideration towards other alternative options [31].

This study assesses energy (electricity)-for-water (also called energy intensity and energy embeddedness) in the urban water cycle of Benidorm based on collected primary data. The data reveal the costs involved in order to improve the water cycle towards a more sustainable path. The analysis includes domestic hot water [32-34] and water boosters for high-rise buildings [35,36] in the end-use phase. In order to reflect the complex water supply system that alters water sources depending on their availability, four extraction scenarios are designed based on precipitation. The results emphasize the importance in water-energy nexus thinking of how water scarcity and uncertainty are dealt with by transferring the problem from water to energy, mainly through the introduction of desalination plants.

The paper is organized as follows. In the next section, Benidorm as a city of successful mass tourism is introduced. Then, the methodology is explained. Section 4 presents the urban water cycle, the various stakeholders involved, and the influence of energy in the water cycle. Then, the results of energy (electricity)-for-water are presented for each stage of the urban water cycle. The paper ends with a section summarizing different energy intensities for different climate scenarios followed by a conclusion.

\section{Benidorm: The Epitome of Mass Tourism}

Benidorm is a mass tourist enclave in the province of Alicante, based on the model of "sun and sand", and a successful example of an international vacation site surviving economic crisis and forecasted inevitable declines [37,38]. Today, Benidorm is the third most visited tourist destination in Spain after Barcelona and Madrid, attracting annually around 2 million visitors with 11 million overnight stays $[39,40]$. During the peak season, the city population is about four times the permanent population, which increases pressures on resources enormously.

Tourism activities make Benidorm a large consumer of water and energy. Every year, about 10 million cubic meters, or approximately half of the total water supplied in the Marina Baja area, is consumed in Benidorm. $64 \%$ of water use in Benidorm is dedicated to tourist, recreational, and commercial activities, while around 30\% is for permanent residents (around 30\% of the permanent residents in Benidorm are foreigners) (Figure A1, Table A1). Energy consumption also demonstrates similar use patterns per sector. $29 \%$ of this figure derives from the residential sector (134 GWh); $2 \%$ from the industrial sector $(7.6 \mathrm{GWh})$, and $69 \%$ from the service sector, including hotels ( $311 \mathrm{GWh}$ ). The total energy consumption in 2015 for Benidorm was 453.6 GWh [41].

However, the success of Benidorm as a tourist destination faces important challenges as periodic droughts that last 2 or 3 years in extreme cases challenge the local water supply systems. Ensuring sufficient water and promoting efficiency has been the primary goal of water management in the city. For example, water losses in supply have been reduced to a minimum of $5 \%$ through a highly optimized distribution network [22]. Moreover, Benidorm has succeeded in cutting its water consumption per capita by $25 \%$ during a period in which the population doubled [42]. Today, 
the complex water supply system developed from accumulated managerial practices during the past forty years in principle allows Benidorm to have sufficient water for its needs (Figure 1).

Water saving campaigns are being promoted with a particular emphasis on the hotel sector through the implementation of water saving equipment in bathrooms. Some studies have found out that hotel vacationers typically use three times more water than an average household [20]. In Benidorm, the water consumption of hotels varies between 147 and 361 liters per bed occupied with a tendency towards higher consumptions in higher hotel categories [7,39]. Energy savings and green energy use are also promoted extensively mainly to reduce costs. During the last few years, electricity from energy companies specializing in renewable energy supply has been offered at better prices to hotels with a membership in the HOSBEC (Hoteliers Association in Benidorm, Costa Blanca, and Valencian Community, in Spanish Asociación Empresarial Hostelera de Benidorm, Costa Blanca y Comunidad Valenciana) association. However, $\mathrm{CO}_{2}$ emission management has still not been implemented in most of the hotels.

Benidorm is unequivocally singular in its compact vertical expansion and density, with less than $5 \%$ of the housing stock built between 1996 and 2005 pertaining to single houses or condominiums. There are 77 buildings higher than 25 floors, of which 27 reach more than $100 \mathrm{~m}$ in height. This character has allowed the city to be efficient in its resource and space use [22,43]. On the other hand, however, vertical urban growth increases energy (electricity)-for-water. This needs to be supplied vertically, creating larger end-use energy intensities [44]. Studies on the energy requirements for pumping in an urban water supply demonstrate that the average energy consumption of residential buildings equals $45 \%$ of the pumping energy needed to deliver water from treatment plants to apartments in a building [39].

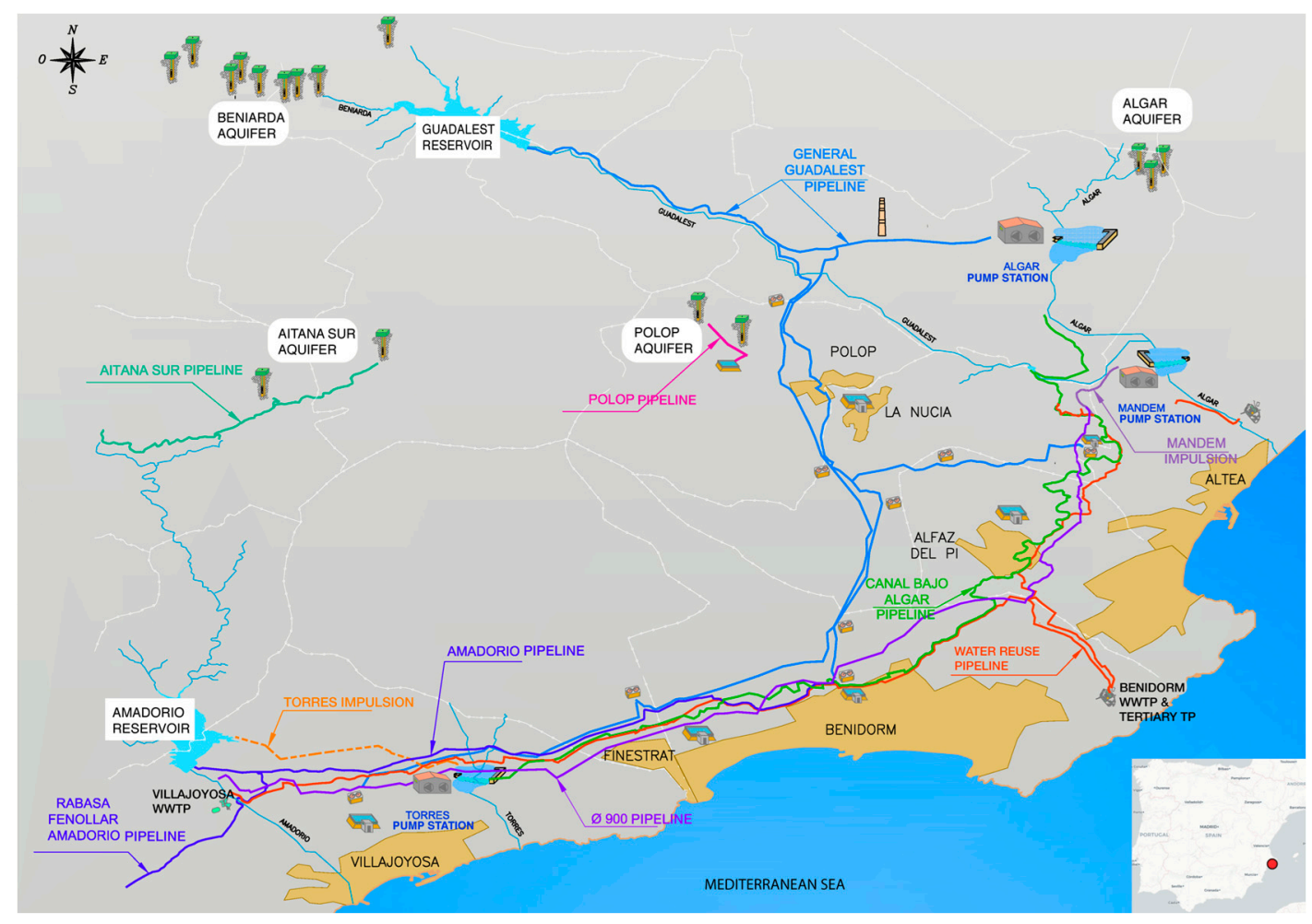

Figure 1. Map of water supply system in Benidorm and the Marina Baja Region (Source: Adopted from Marina Baja Water Consortium). 


\section{Materials and Methods}

The water-energy nexus is approached from the energy intensity or energy embeddedness of water flows in the urban water cycle of Benidorm following the methodology developed by the California Energy Commission [2]. Quantitative data were collected through email requests followed up by three field trips in June 2015, November 2015, and June 2016. A total of nine meetings with key stakeholders-a water company, wastewater treatment plant managers, the Marina Baja Water Consortium (Consorcio de Aguas de la Marina Baja in Spanish, hereafter called the Consortium), tourist boards, and hotel groups-added important insights on water management in Benidorm. Based on the data collected, the energy intensity of water provision was calculated for water extraction, transportation, end-uses, treatment, and reuse. Since the urban water supply of Benidorm relies on electricity as the main energy source, most of the data collected are electricity data. The only exception affects end use where various types of energy are commonly used for hot water. Last, in order to consider climate variations and their influence in the water-energy nexus, different energy requirements for water supply were computed based on different water supply options. These calculations were provided by the Consortium based on data from the past 25 years of experience in water management by this organization. Data collection posed several challenges due to the lack of detailed information on water and energy at the municipal level, and therefore it was supplemented with a set of plausible hypotheses in order to reconstruct a model able to fit the system boundary. These hypotheses are explained in the results section along with other details of the calculations. The lack of data also challenges the robustness of the analysis performed in this study. Water data may imply errors of 6 to $11 \%$ depending on the water source. At any rate, we believe that our calculations may serve as a benchmark for other cases as this is one of the first studies conducted on energy (electricity)-for-water in a large mass tourist center. The year 2014 was selected as the base year except for end uses and energy intensities associated with emergency water transfers (Table A2).

Energy (electricity)-for-water is calculated by dividing the quantity of water by the energy required for each phase of the cycle (1). The unit used is $\mathrm{kWh} / \mathrm{m}^{3}$, where at stage $i$ and at year $t, E w_{i, t}$ stands for energy (electricity)-for-water, $E_{i, t}$ for energy required, and $W_{i}$ for water produced or treated.

$$
E w_{i, t}=\frac{E_{i, t}}{W_{i, t}}
$$

When there are several plants or processes involved within a stage (for example, water extraction, water treatment plant, and wastewater treatment plant), in order to take into account the total energy (electricity)-for-water, the following equation is applied, where $S E_{i}$ refers to the sum of energy required within stage $i$ and $S W_{i}$ to the total amount of water produced or treated within a stage.

$$
E w=S E_{i} / S W_{i}
$$

Among numerous factors, precipitation is one of the main parameters that affect the physical availability of surface water and groundwater. Thus, the energy intensity of water supplied to Benidorm is not fixed but dynamic depending on precipitation. To take this into account in this study, changing energy intensities in different climatic conditions are compared by hypothesizing four scenarios, namely dry (A), dry (B), normal, and wet years. To each water source, a coefficient (c) varying between 0 and $100 \%$ is applied with the purpose of comparing energy intensity for withdrawal by applying the equation below.

$$
E w_{\text {extraction }}=\sum_{j=0}^{n} c_{j} \cdot E w_{j}
$$


Table 1 illustrates the coefficient value for different options for extraction $(j)$ according to four different scenarios.

Table 1. Coefficients on the supplied amount of water per source depending on scenario.

\begin{tabular}{|c|c|c|c|c|}
\hline Scenarios & Dry (A) & Dry (B) & Wet & Normal \\
\hline 1. Wells Algar/pumping Algar & $9.6 \%$ & $9.6 \%$ & $28.0 \%$ & $21.2 \%$ \\
\hline 2. Wells Beniardà & $28.5 \%$ & $28.5 \%$ & $1.7 \%$ & $15.1 \%$ \\
\hline 3. Interbasin transfer & $48.4 \%$ & - & - & - \\
\hline 4. Amadorio reservoir & $13.5 \%$ & $13.5 \%$ & $70.3 \%$ & $63.7 \%$ \\
\hline 5. Desalination plant & - & $48.4 \%$ & - & - \\
\hline
\end{tabular}

Considering that water withdrawn in the Marina Baja area is sent to seven municipalities, including Benidorm, the total energy use for water supply in Benidorm is estimated by applying the proportion of water supplied to Benidorm over the total water supplied in the Marina Baja in 2014 (Table A1). The proportion ranges from 51 to $59 \%$ with an average of $54 \%$ over the past 25 years. This option was considered more reasonable than simply applying proportions from population data as the number of residents does not include tourists.

The energy needed for the end use of water is best captured in Benidorm through the case of the domestic and hotel sectors as their hot water use and water pumping are the two main nexus points. Since hot water is not metered separately, Spanish national statistics for domestic hot water use were used as proxies. On the other hand, hot water use at hotels was calculated based on data collected from a four-star hotel. The data provided daily hot water and diesel consumption over a period of 5 years that supplemented solar water heating system. Energy intensity for water pumping is calculated by the following equation:

$$
\mathrm{P}=\frac{\mathrm{q} \rho \mathrm{gh}}{\eta_{\mathrm{c}}}\left[k W\left(\text { or } \frac{k N \cdot m}{\mathrm{~s}}\right)=\frac{\mathrm{m}^{3}}{\mathrm{~s}} \cdot \frac{\mathrm{kN}}{\mathrm{m}^{3}} \cdot \mathrm{m}\right]
$$

where $\mathrm{P}$ is the power for lifting water, $\mathrm{h}$ is water lift height, $\mathrm{g}$ is gravity, $\mathrm{q}$ is flow through the pipe, and $\rho$ is the specific density of the water. Due to different pumps installed and varying loads, design parameters are defined to simplify the calculations to predict the energy requirement. For simplicity, the overall efficiency ( $\eta \mathrm{c}$ ) 0.5625 [35] is selected based on the fact that the pump efficiency ranges between 50 and $80 \%$, the mechanical transmission efficiency is about $90-100 \%$ accounting for the power transmission between the motor and pump, and the electricity motor efficiency is 70-90\% [45]. The energy intensity for water pumping $\left(\mathrm{E}_{w, \text { pump }}\right)$ is calculated, where $\mathrm{n}$ is the pumping capacity $\left(\mathrm{m}^{3} / \mathrm{h}\right)$ and the friction loss $(\alpha)$ within the pipe is assumed to be $30 \%$, as follows [44]:

$$
\mathrm{E}_{w, \text { pump }}=\frac{\mathrm{P}(1+\alpha)}{\mathrm{n}}\left[\frac{k W h}{m^{3}}=\frac{k W}{m^{3} / h}\right] .
$$

Some authors warn about the limitations of this approach, as habits regarding energy and water use vary and, therefore, the nexus (energy intensity and water intensity) is difficult to generalize especially for end uses [17]. Despite criticisms, the generalized approach is useful as it helps to estimate the nexus when microdata generation and collection is difficult and costly. Finally, and due to limited data availability, the carbon emissions for energy (electricity)-for-water were not included in this study. 


\section{Results}

\subsection{Energy in the Urban Water Cycle of Benidorm}

The urban water cycle of Benidorm has been developed in response to a series of droughts of different intensity and impact. The episode of 1978 is recorded as the worst water crisis in the history of the city. After sources of water supply dried out, Benidorm had to resort to shipped water from the port of Alicante by tanker in what locals named Operación Barco. Other drought episodes followed in subsequent years from 1981 to 1984, 1992 to 1996, 1999 to 2001, and most recently in 2015. However, none had the gravity and impact of that of 1978. Although it was created a few months before of the water crisis of 1978, the Water Consortium of the Marina Baja, formed by seven municipalities, the Provincial Council of Alicante, and the Júcar River Basin Authority, had the basic aim of avoiding the occurrence of water scarcity episodes in the Benidorm area. First, the water supply network connected surface water and groundwater (Algar-Guadalest-Amadorio) sources through the Torres, Mandem, and Algar pump stations. Later, during the prolonged drought of 1992-1995, the Rabasa-Fenollar-Amadorio pipeline, with a total length of $47,860 \mathrm{~m}$ and a maximum flow rate of $910 \mathrm{~L} / \mathrm{s}$, was connected to water from the Tajo-Segura interbasin aqueduct.

Beyond more conventional hydraulic solutions, one of the most distinctive features of the urban water cycle in Benidorm is the use of non-conventional flows based on the agreements between several agricultural communities and the water authorities of the region. In accordance with the agreement, the agricultural communities provide clean water to the city in exchange for treated wastewater of a quality high enough to be used in irrigation. This scheme has been valued positively, but it was considered a case difficult to interpret in traditional water market terms because the transactions were established without formal pricing [22]. Rather, according to the agreements, the right of Benidorm and other cities to exploit aquifers for clean water is granted in exchange for payments for pumping costs (electricity) of irrigation communities that range between $€ 420,000$ and $€ 600,000$ per year. Even though water is handed at no value, the water-energy nexus reveals that energy costs are also at the center of this water exchange scheme. The energy costs of these agreements also appear in the need to lower conductivity values in the wastewater for their use in irrigation. In 2006, a desalination unit was added to the wastewater treatment plant of Benidorm to lower conductivity values below $1300 \mu \mathrm{S} / \mathrm{cm}$. Hence, energy was also at the center of non-conventional solutions for the urban water cycle of the city.

In 2015, the Muchamiel desalination plant (52 m above sea level (a.s.l.)) was added to the urban water cycle of Benidorm as part of the A.G.U.A. Program ("Actuaciones para la Gestión y Utilización del Agua") of the Spanish Ministry of Agriculture, Fisheries, Food, and Environment. The plant uses reverse osmosis technology to produce potable water from seawater. Muchamiel is located $35 \mathrm{~km}$ from Benidorm. Therefore, additional energy inputs are required for water transportation via pipeline to reach the city. To date, the water produced cannot be supplied to Benidorm because the pipeline connection remains incomplete. Instead, the plant supplies water to Alicante, which suffered a severe drought in 2015. The pipeline between Muchamiel and Benidorm remains disconnected because litigation on an unjust bidding process for the pipeline's construction has put the project on hold [46]. However, since it was built with the objective of providing water to Benidorm, the study takes this facility into account as an important prospective water source to be incorporated into the water cycle of the city.

The urban water cycle of Benidorm is depicted in Figure 2 based on the water moved at each stage along with the institutions in charge of each part of the cycle. The Marina Baja Water Consortium, a public, supra municipal company, is responsible for water supply to Benidorm and nearby municipalities. Water purification and urban water distribution in Benidorm are performed and managed by Hidraqua, a private company, who has formed a partnership with the municipality. Finally, a wastewater treatment plant is managed by the public entity EPSAR. 


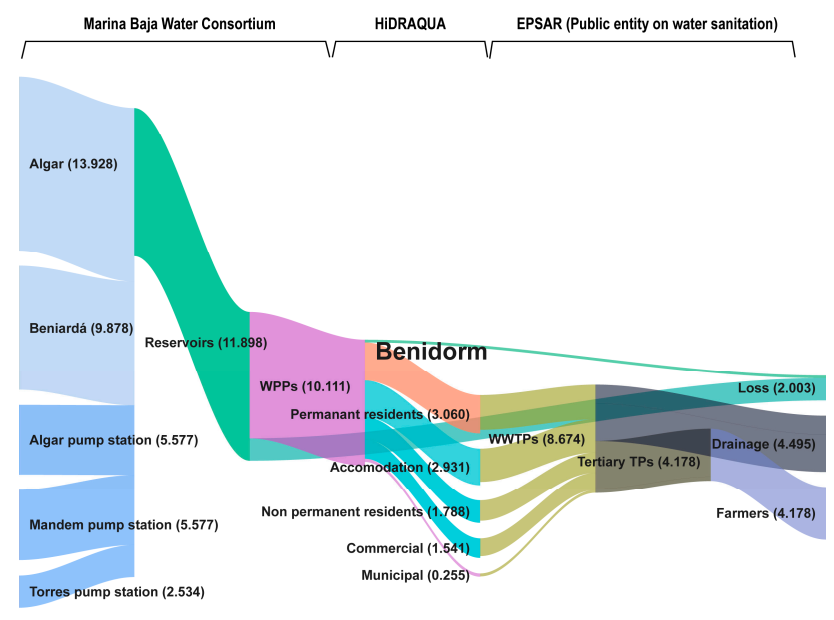

Figure 2. The urban water cycle of Benidorm in 2014: the system boundary of this study (unit: million $\mathrm{m}^{3}$ ). WPPs: water purification plants; WWTPs: wastewater treatment plants; TPs: treatment plants.

In sum, a varied number of entities of different character and scale govern the water cycle in Benidorm. Furthermore, as desalination and the reuse of wastewater have been spotlighted as one of the key alternative technologies for water management in arid areas [21], both of them are present in the urban water cycle of Benidorm with important implications for energy use. In the following part, the energy (electricity)-for-water in each stage of the cycle is presented.

\subsection{Energy (Electricity)-for-Water: Quantitative Analysis}

Figure 3 illustrates the average energy intensity of the urban water cycle of Benidorm in 2014. The range of energy intensity is summarized in Appendix A Table A3. The total energy use for the urban water cycle of Benidorm is estimated to be on average $109 \mathrm{GWh} /$ year. The figure represents a normal condition and does not include the energy intensity of emergency water systems that are activated only in cases of severe drought. Further analysis on the use of the emergency water system is presented in Section 4.3.

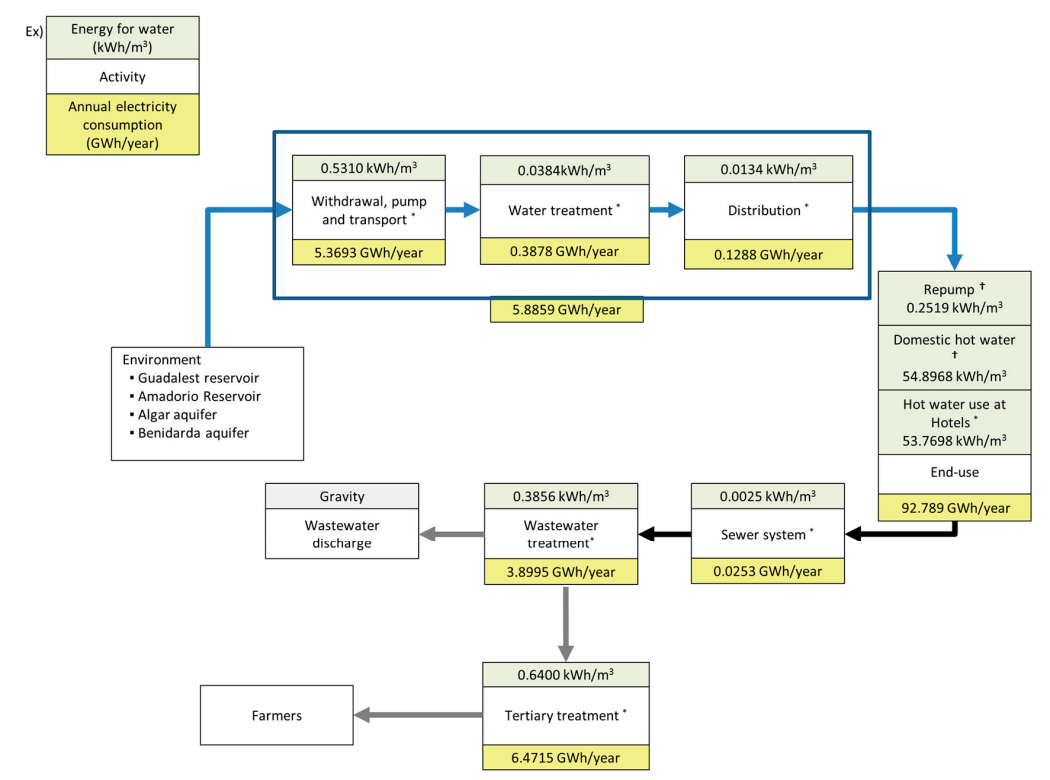

Figure 3. Energy(electricity)-for-water for Benidorm in 2014 ( ${ }^{*}$ mark values calculated based on primary data and + mark those calculated based on primary and secondary data). 


\subsubsection{Withdrawal, Transport, Treatment, and Distribution}

Water withdrawal for Benidorm relies on surface water from the Amadorio (95 m a.s.l.) and Guadalest (350 m a.s.l.) reservoirs and groundwater from the Beniardà and Algar aquifers. Three large pump stations capture these water flows. The Algar pump station sends water to the Guadalest reservoir. The Mandem pump station, located at the conjunction of the Algar and Guadalest rivers, sends water to the Canal Bajo del Algar pipeline. The Torres pump station, pumping excess water from the Algar-Guadalest basin and the Torres River, is connected to the Amadorio reservoir and operates when it rains. For urban supply, water is transported through gravity without additional energy input. The topography of the reservoir and the conveyance system allow water to be efficiently delivered to the city. For surface water, the energy intensity of the pumping stations oscillates between 0.17 and $0.96 \mathrm{kWh} / \mathrm{m}^{3}$. Groundwater extraction requires a higher energy intensity of $0.35-0.78 \mathrm{kWh} / \mathrm{m}^{3}$. The total energy intensity for withdrawal, pumping, and transportation accounts for $0.5310 \mathrm{kWh} / \mathrm{m}^{3}$ (Figure 4).

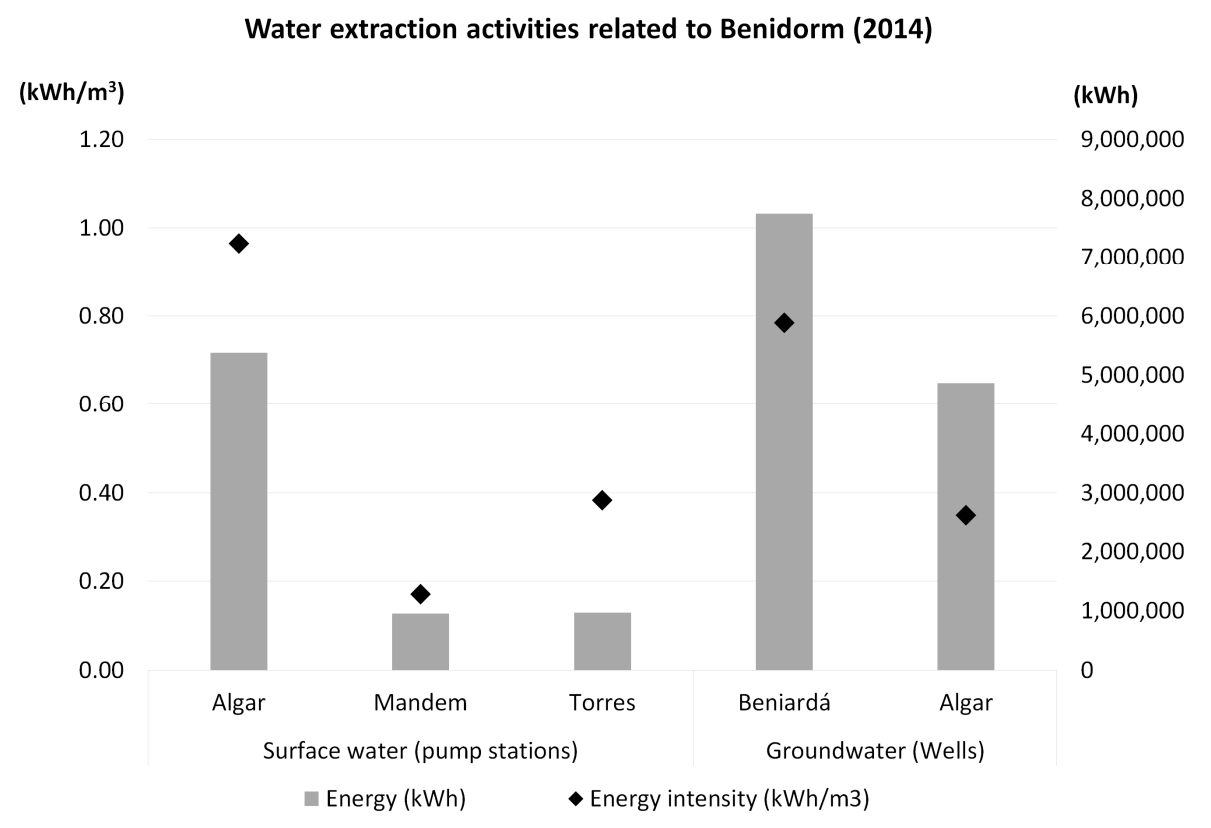

Figure 4. Water extraction activities in Marina Baja related to Benidorm's urban water supply.

Before arriving in the city, water goes through treatment for purification in the Benidorm $\left(0.0311 \mathrm{kWh} / \mathrm{m}^{3}\right)$ and Galandú $\left(0.0726 \mathrm{kWh} / \mathrm{m}^{3}\right)$ plants. Purified water is then distributed to the city, with $0.0134 \mathrm{kWh} / \mathrm{m}^{3}$ required to meet the minimum water pressure.

In total, fresh water withdrawal, pumping, and transportation required $3.8 \mathrm{GWh}$ in 2014. From withdrawal to the distribution of water to the city, about $5 \mathrm{GWh}$ is consumed every year in Benidorm.

\subsubsection{End Uses: Hot Water Use and Water Pumping for Buildings}

Water, as hot water, carries heat and provides people with convenient, comforting, and vital services, such as hot showers and baths (including spa-type devices), washing, cleaning, and cooking. According to a study conducted by Kempton [47], energy use for domestic water heating oscillates between 1.8 and $4.7 \mathrm{kWh} /$ day. Domestic hot water use in Benidorm is estimated based on the average water heating data provided by Spanish Environmental indicators (Banco Público de Indicadores Ambientales (BPIA)). In Spain, the annual average domestic energy consumption for hot water is $1755.90 \mathrm{kWh}$ per household. Thus, $1.902 \mathrm{kWh} /$ person-day are required for domestic hot water considering an average household size of 2.53 persons (INE 2013). The domestic water consumption 
for inhabitants of Benidorm is $0.192 \mathrm{~m}^{3}$ /person-day. Assuming that, on average, $18 \%$ of domestic water is used as hot water [48], an energy intensity of $54 \mathrm{kWh} / \mathrm{m}^{3}$ is estimated for domestic hot water use in Benidorm. Based on data provided by a four-star hotel during 2010 to 2015, on average, $25.5 \%$ of the water used in hotels is for hot water. The calorific value of $10.61 \mathrm{kWh} / \mathrm{L}(83.19 \mathrm{MJ} / \mathrm{L})$ was applied for unit conversion. Therefore, an average energy intensity of $53.8 \mathrm{kWh} / \mathrm{m}^{3}$ (standard deviation 4.63) is estimated for hot water use in hotels in Benidorm, with energy intensity ranging from 49.8 to $64.0 \mathrm{kWh} / \mathrm{m}^{3}$. Hotels in Benidorm tend to spend much more energy for water heating than residents, as most hotels still use central oil boilers fuelled with diesel and use larger quantities of water compared with the residential sector.

The second consideration is the energy required for water pumping within the buildings as Benidorm stands out for its skyscraper landscape [49]. Water pumping in high buildings is gaining attention, for example in China, as the number of high skyscrapers is expanding and buildings are becoming increasingly tall $[35,36]$. In our case, the maximum heights of all types of buildings (hotel or residential) were calculated from cadastral data of the Spanish Ministry of Finance and Public Administration) [50]. Pump height was calculated as an average height, excluding the buildings lower than or equal to four floors $(\leq 12 \mathrm{~m})$, with the story height assumed to be $3 \mathrm{~m}$. By applying Equations (4) and (5) (refer to Section 3), the energy needed for pumping water in tall buildings is estimated to be about $0.2519 \mathrm{kWh} / \mathrm{m}^{3}$ (Table 2).

Table 2. Estimation for pumping water in buildings applying Equation (4).

\begin{tabular}{ccc}
\hline Variables & Amount & Units \\
\hline Specific weight of water & 9.81 & $\mathrm{kN} / \mathrm{m}^{3}$ \\
Pump height & 40 & $\mathrm{~m}$ \\
Flow (of water registered) & 0.3036 & $\mathrm{~m}^{3} / \mathrm{s}$ \\
Overall efficiency & 0.5625 & \\
Energy intensity for repumping water & 0.2519 & $\mathrm{kWh} / \mathrm{m}^{3}$ \\
\hline
\end{tabular}

\subsubsection{Wastewater Treatment Plants}

Wastewater from Benidorm is directed to the Benidorm and Villajoyosa wastewater treatment plants (WWTP). The WWTP of Benidorm (143 m a.s.l.), with a capacity of $60,000 \mathrm{~m}^{3} /$ day and an average flow rate of $36,490 \mathrm{~m}^{3} /$ day (2015), shows an energy intensity of $0.35 \mathrm{kWh} / \mathrm{m}^{3}$, which is smaller than U.S. $\left(0.407 \mathrm{kWh} / \mathrm{m}^{3}\right)$ and Australian $\left(0.46 \mathrm{kWh} / \mathrm{m}^{3}\right)$ plants $[14,51]$ and the WWTP of the Spanish coastal resort of Calafell, which has an energy intensity of $0.457 \mathrm{kWh} / \mathrm{m}^{3}$ [52]. The biogas cogeneration in the Benidorm WWTP helps in saving $25 \%$ of the total electricity required. In monetary terms (applying an electricity price of $0.10 € / \mathrm{kWh}$ ), the energy savings from the cogeneration system would amount to $€ 140,000$ per year on average. This has helped the plant to reduce energy costs when it cannot meet the optimal treatment level due to fluctuations of water use during the low tourist season. The Benidorm Tertiary water treatment plant, equipped with ultrafiltration and reverse osmosis systems, needs an energy equivalent of $0.64 \mathrm{kWh} / \mathrm{m}^{3}$. The treatment is adjusted to meet the demand from irrigators. Therefore, in periods with sufficient rain the plant diminishes its activity. The water treated per year oscillates between $2,000,000 \mathrm{~m}^{3}$ and $4,000,000 \mathrm{~m}^{3}$ and operates on average $16 \mathrm{~h}$ a day treating $24,000 \mathrm{~m}^{3}$.

The WWTP of Villajoyosa has a smaller treatment capacity compared to that of Benidorm and only treats the wastewater generated from the Poniente section of Benidorm. This plant has an average energy intensity of $0.54 \mathrm{kWh} / \mathrm{m}^{3}$. In total, $6.3 \mathrm{GWh}$ of electricity is consumed annually to treat wastewater from Benidorm and other towns in the Marina Baja, of which $3.8 \mathrm{GWh}$ per year is estimated to be spent in Benidorm. 


\subsubsection{Emergency Water Provision}

Benidorm may resort to an emergency water provision scheme, which becomes the vital water source for the city in severe drought periods. The existing scheme activates interbasin transfers when prolonged droughts reduce the water level in the Guadalest and Amadorio reservoirs. In these cases, the interbasin water transfer from the Rabasa-Fenollar-Amadorio system supplies water from the Canales de la Mancomunidad del Taibilla, $60 \%$ of which is desalinated water [53]. Pumping water from the vicinity increases energy intensity moderately compared to surface water and groundwater use in the Marina Baja. Based on data from 2001 to 2015, the average energy intensity of this system is $0.79 \mathrm{kWh} / \mathrm{m}^{3}$. (Note that this does not include the energy intensity required to withdraw water in the Mancomunidad water system, which also includes desalination plants).

In addition, and as mentioned above, the Muchamiel desalination plant will be added to the urban water cycle of Benidorm. According to operational data from July to December 2015, the plant has an average energy intensity of $3.27 \mathrm{kWh} / \mathrm{m}^{3}$ with a monthly water production between $539,753 \mathrm{~m}^{3}$ and $1,061,242 \mathrm{~m}^{3}$ (average $683,380 \mathrm{~m}^{3}$ ) working approximately at $45 \%$ of its capacity (Table 3 ). However, this energy intensity will increase as additional pumping would be required to transport water through the existing Rabasa-Fenollar-Amadorio pipeline to Benidorm. Assuming that this does not take into account water transportation from the plant to the city through the existing emergency pipeline, it can be estimated that the energy requirement would increase to $4.064 \mathrm{kWh} / \mathrm{m}^{3}$.

Table 3. Muchamiel desalination plant performance data from July to December 2015.

\begin{tabular}{cc}
\hline Category (unit) & Values \\
Amount of water produced $\left(\mathrm{m}^{3}\right)$ & $4,100,280$ \\
Energy consumed $(\mathrm{kWh})$ & $13,413,380$ \\
Total energy cost $(€)$ & $1,087,637$ \\
Energy cost per water produced $\left(€ / \mathrm{m}^{3}\right)$ & 0.2653 \\
Energy cost per energy consumed $(€ / \mathrm{kWh})$ & 0.0811 \\
\hline
\end{tabular}

\subsubsection{Others}

Other activities related to the water cycle-sewage system, discharge, and grey water distribution-require energy. Sewage systems transporting sewage and surface runoff require a minimum amount of water, which in 2014 accounted for $0.0025 \mathrm{kWh} / \mathrm{m}^{3}$. Discharge of water requires no energy as gravity is used. Farmers pump up the treated water needed for their farms from the tertiary treatment plant, but since electricity use is measured individually in the farms, data is very hard to obtain. Thus, this stage of the water cycle was not included in the energy (electricity)-for-water calculation.

\subsection{Desalination: A Blessing or a Burden?-ScenarioAnalyses}

Among various factors, precipitation conditions play a pivotal role in deciding which water source is withdrawn for use. In this section, the results of energy (electricity)-for-water are assessed according to three precipitation scenarios: wet, normal, and dry years, with the dry years further divided into two scenarios.

During years with abundant rain, the Torres pump station directs water to the Amadorio reservoir. Surface water provides sufficient water for supply, and consequently the need to pump groundwater decreases. Furthermore, pumping from the Algar aquifer requires less energy as the water head rises. In a normal season, the water is provided from the Amadorio reservoir but groundwater pumping from aquifers is required. During a dry season, surface water often runs out, and groundwater pumping increases to provide water for urban uses following the agreements between the farmers and the Consortium. When surface water runs out, the emergency Rabasa-Fenollar-Amadorio 
interbasin transfer starts operating in collaboration with the Mancomunidad de los Canales del Taibilla. This interbasin water transfer provides close to $50 \%$ of the water required in Benidorm.

Our results show that energy intensity increases as dry climate conditions lower the water stored in reservoirs (Figure 5). In a dry year, the Rabasa-Fenollar-Amadorio interbasin transfer is activated and this results in increasing energy intensity up to $0.75-1.2 \mathrm{kWh} / \mathrm{m}^{3}$, more than twice the energy intensity of normal years. If the Muchamiel desalination plant is incorporated by substituting it for the emergency interbasin transfer, the total amount of desalted water in the urban water cycle would increase. Compared with the options used in normal years, desalination increases the energy intensity by a factor of 6 . The introduction of the Muchamiel desalination plant in Benidorm demonstrates a paradoxical reality whereby high construction and energy costs were not considered a serious impediment. This results in the production of desalted water that is high in energy intensity and therefore more expensive. Consequently, it requires subsidies or an exemption on amortization to lower the water price and make it affordable for users.

During wet years, the energy (electricity)-for-water for withdrawal remains around $0.33 \mathrm{kWh} / \mathrm{m}^{3}$. Most of this energy is used to pump water so that as much excess water as possible could be stored in the reservoir. During the period when there is plenty of water, the Algar aquifer overflows and reduces the level of energy required. During a normal year, $0.38 \mathrm{kWh} / \mathrm{m}^{3}$ is required for maintaining the balance of pumping water from reservoirs and aquifers.

Dry B: Dry year with desalination

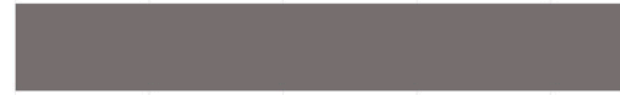

Dry A: Dry year with interbasin transfer

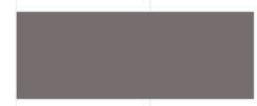

Wet year

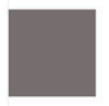

Normal year

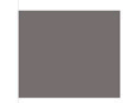

0.00

0.50

$1.00 \quad 1.50$
$\left(\mathrm{kWh} / \mathrm{m}^{3}\right)$

2.00

2.50

Figure 5. Results of energy (electricity)-for-water per scenario.

\section{Discussion}

The results obtained show that $4 \%$ of the total energy consumption in Benidorm is dedicated to water supply and treatment (water withdrawal, transport, purification, and waste treatment). Water purification is low in energy intensity as the quality of groundwater and surface water requires minimum treatments. The energy intensity for wastewater treatment is known to increase as the treatment technology advances in sophistication. In this case, the energy intensity of the tertiary treatment plant increases and consequently doubles the energy required for secondary treatment. In Benidorm, additional energy intensity from adding tertiary treatment is inevitable not only to guarantee the water quality of the effluent but also to respect the agreements with irrigation communities for water reuse.

The most energy-intensive stage was end uses, which accounted for $20 \%$ of the total energy use when the energy required for water pumping and hot water use was considered. This highlights the relevance of considering the water-energy nexus from both the supply and the demand sides [1]. Considering that other energy uses for water (swimming pool maintenance, laundry, etc.) were not 
included in this study due to data availability, it is likely that the energy intensity in end uses might be slightly larger. Conversely, as the weather in Benidorm tends to be milder compared to other parts of Spain, it is also possible that domestic hot water use may be lower than average. Vertically developed Benidorm requires further attention compared with other horizontally developed coastal towns in Spain because the compact model bears a special type of energy use that may not be necessary for low-rise buildings.

The energy (electricity)-for-water per precipitation scenario demonstrates that energy intensity varies as much as $600 \%$ depending on the water option selected in dry years, which raises sustainability questions. Energy intensity is highest when desalinated water is used. This is reflected in high water prices, which make water from desalination less attractive compared to other water sources. The desalination plant of Muchamiel, the water of which is imposed over other options, may bring tensions to the existing urban water cycle arrangements.

On the other hand, the current water agreements between farmers and the Water Consortium of the Marina Baja imply using the same technology (reverse osmosis) as the desalination plant. The same technology applied to different contexts (i.e., site, scale, and water quality requirements) results in increasing energy intensity for wastewater treatment but below that of desalination plants.

While the water agreements with irrigators provide a safe environment to secure water, Benidorm is not free of tensions and conflicts over the resource. For example, the farmers of Callosa d'en Sarria rely on their aquifer water and do not comply with the water agreements as they oppose the Consortium [54,55]. Moreover, hotels and amusement parks in Benidorm are accused by the farmers of worsening water quality by inappropriately discharging salty water to the drains from their premises [56]. In this respect, it must be remembered that many hotels maintain private wells with water of high salt content used for cleaning tasks [56].

Last, contractual terms with the electricity company pose operational difficulties in managing water due to the rigid requirements enforced when defining the contracted power. An annual contract with a fixed contracted power lacks flexibility to account for the fluctuating power requirement, which depends on the water situation of the region. This is a problem not only for the consortium but also for other entities as it is difficult to foresee the water situation. This results in adding fixed costs to water, as water managers are forced to maintain a high-voltage electricity supply throughout the year even when precipitation levels do not require further energy inputs. Thus, there is a discrepancy in the socio-technological arrangements of energy and water, whereby a lack of contractual flexibility of the energy sector may become an obstacle for the water sector.

\section{Conclusions}

In this paper, energy (electricity)-for-water was explored in Benidorm, a mass tourist center where water acts as a major player in the development of the tourism industry. Benidorm exemplifies a case of increased energy intensity to ensure water, especially in conditions of water stress. In this sense, the Muchamiel desalination plant, which will be introduced in the water cycle of Benidorm, may change the notion of water scarcity and availability by providing a resource not bound by climatic constraints. However, the result of the study warns that it may transfer water constraints to energy as its energy intensity is three times higher than the existing emergency interbasin transfer and six times higher than the normal water provision scheme. This new technological fix imposed by national water authorities may act as an external pressure to change the existing urban water cycle at the local level in several ways, either prompting more conservation and efficiency measures because of high prices or discouraging these if the perception of an ample and limitless supply gains adherents in the tourist sector. Desalted water has a cost beyond the purchasing power of farmers. However, national authorities are already planning to restructure these high water costs by allowing exemptions for the amortization of the construction costs, as the project has an 'environmental character' [57]. Given the unreliability of current supplies in face of climate change and the potential socio-territorial conflicts associated with interbasin transfers, desalination may become the only feasible alternative. To avoid 
transferring the problem from water to energy, Benidorm should work forward the nexus findings through a greater integration of research and policy across both sectors.

Acknowledgments: The authors would like to acknowledge the Consorcio de Aguas de Marina Baja, Hidraqua, Depuración de Aguas del Mediterráneo, Acuamed, and Aguas de Barcelona for the support provided in data collection. Specially, we thank also the following individuals: Francisco Santiago, Jaime Berenguer, Ana Arahuetes Hidalgo, and Juan Díaz for helpful suggestions and Benito Zaragozí for his support in obtaining the height of the Benidorm buildings. Finally, the authors would like to thank Xavier Gabarrell and anonymous reviewers for comments on an earlier version of the manuscript. This work was supported by the Spanish Ministry of Economy, Industry, and Competitiveness under the Grants BES-2013-066420 (to Hyerim Yoon) and CSO2015-65182-C2-1-P (Research project "Uso de recursos hidricos no convencionales y adaptacion a las sequias en el litoral mediterraneo: realidades y propuestas para una planificacion resiliente del agua").

Author Contributions: Hyerim Yoon and David Sauri conceived and designed the experiments; Hyerim Yoon and Antonio M. Rico Amorós collected the data; Hyerim Yoon analyzed the data; and Hyerim Yoon wrote the paper with David Sauri and Antonio M. Rico Amorós.

Conflicts of Interest: The authors declare no conflict of interest. The founding sponsors had no role in the design of the study; in the collection, analyses, or interpretation of data; in the writing of the manuscript, and in the decision to publish the results.

\section{Appendix A}

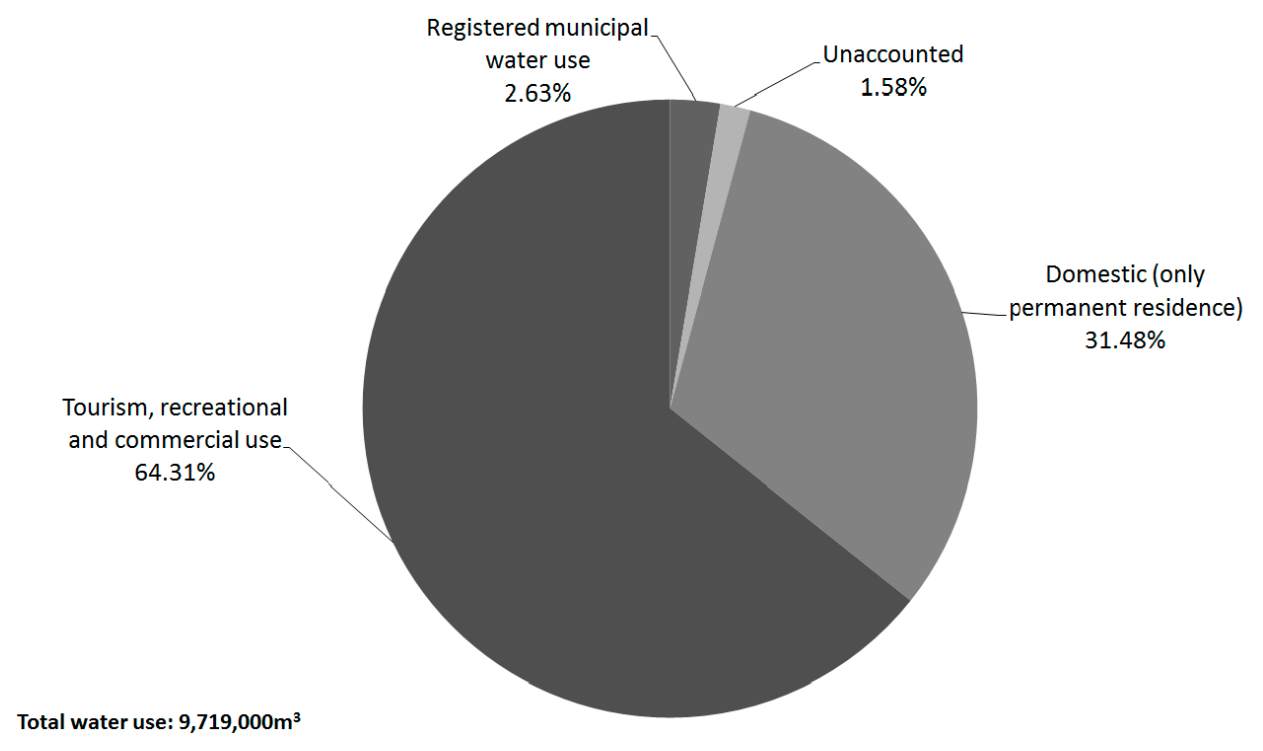

Figure A1. Water use in Benidorm (Source: Hidraqua).

Table A1. Inhabitants and water consumption in 2014 per member municipalities to consortium (Source: Spanish Statistical Office, Cosortium).

\begin{tabular}{cccc}
\hline Municipality & Inhabitant & Water Billed $\left.\mathbf{( m}^{\mathbf{3}}\right)$ & Water Provision per Capita per Day 1/Capita/day \\
\hline L'Alfàs del Pi & 21,357 & $2,392,755$ & 306.95 \\
Altea & 22,518 & $1,819,165$ & 221.33 \\
Benidorm & 69,010 & $10,111,705$ & 401.44 \\
Finestrat & 6265 & 668,070 & 292.15 \\
La Nucia & 20,029 & $1,538,041$ & 210.39 \\
Polop & 4313 & 524,610 & 333.25 \\
Villajoyosa & 33,951 & $2,285,000$ & 184.39 \\
Callosa d'en Sarrià & 7370 & 0 & 0.00 \\
Total & 177,443 & $19,339,346$ & \\
\hline
\end{tabular}


Table A2. Categories and sources of data collected.

\begin{tabular}{clc}
\hline Category & \multicolumn{1}{c}{ Data Collected } & \multicolumn{1}{c}{ Sources } \\
\hline Extraction & Energy consumed 2014/Water extracted 2014 & $\begin{array}{c}\text { Water Consortium of the } \\
\text { Marina Baja }\end{array}$ \\
\hline Water treatment & $\begin{array}{l}\text { Benidorm: Energy consumed 2014/Water } \\
\text { treated 2014 } \\
\text { Gandalú: Energy consumed 2015/Water } \\
\text { treated 2015 (January-June) }\end{array}$ & HiDRAQUA \\
\hline Distribution & Energy consumed 2014/Water registered 2014 & HiDRAQUA \\
\hline Sewer system & Energy consumed 2014 & HiDRAQUA \\
\hline WWTP(Wastewater treatment plant) & Energy consumed 2014/Water received 2014 & $\begin{array}{c}\text { Wastewater treatment plant } \\
\text { of Benidorm }\end{array}$ \\
\hline Tertiary treatment & $\begin{array}{l}\text { Water received and energy consumed for a } \\
\text { normal year }\end{array}$ & $\begin{array}{c}\text { Tertiary treatment plant } \\
\text { of Benidorm }\end{array}$ \\
\hline $\begin{array}{c}\text { Rabasa-Fenollar-Amadorio } \\
\text { (Emergency water transfer) }\end{array}$ & $\begin{array}{l}\text { Energy consumed 2001\&2015/Water } \\
\text { transferred 2001\&2015 }\end{array}$ & \begin{tabular}{c} 
Acuamed \\
\hline Desalination
\end{tabular} \\
\hline Energy consumed 2015/Water produced 2015 & Acuamed \\
\hline
\end{tabular}

Table A3. Ranges of energy intensity data for the urban water cycle of Benidorm.

\begin{tabular}{lll}
\hline Categories & & Energy Intensity $\left(\mathbf{k W h} / \mathbf{m}^{3}\right)$ \\
\hline \multirow{2}{*}{ Water withdrawal } & Surface water extraction & $0.171-0.964$ \\
& Groundwater extraction & $0.349-0.784$ \\
\hline \multirow{2}{*}{ Emergency water supply } & Interbasin transfer & $0.753-0.832$ \\
& Desalination (water production only) & $3.211-3.334$ \\
\hline \multirow{2}{*}{ Water treatment } & & $0.031-0.073$ \\
\hline Distribution & & $0.012-0.148$ \\
\hline Wastewater treatment & & $0.346-0.542$ \\
\hline Tertiary treatment & & $0.5-0.7$ \\
\hline \multirow{2}{*}{ End use } & Domestic hot water & $47.054-65.876$ \\
& Hotel hot water & $49.800-63.992$ \\
\hline
\end{tabular}

\section{References}

1. Voinov, A.; Cardwell, H. The Energy-Water Nexus: Why Should We Care? J. Contemp. Water Res. Educ. 2009, 143, 17-29. [CrossRef]

2. CEC (California Energy Commission). California's Water-Energy Relationship Final Staff Report; California Energy Commission: Sacramento, CA, USA, 2005.

3. Bartos, M.D.; Chester, M.V. The Conservation Nexus: Valuing Interdependent Water and Energy Savings in Arizona. Environ. Sci. Technol. 2014, 48, 2139-2149. [CrossRef] [PubMed]

4. Patelis, M.; Kanakoudis, V.; Gonelas, K. Pressure Management and Energy Recovery Capabilities Using PATs. Procedia Eng. 2016, 162, 503-510. [CrossRef]

5. World Bank. Cities and Climate Change: An Urgent Agenda; World Bank: Washington, DC, USA, 2010.

6. Nair, S.; George, B.; Malano, H.M.; Arora, M.; Nawarathna, B. Water-energy-greenhouse gas nexus of urban water systems: Review of concepts, state-of-art and methods. Resour. Conserv. Recycl. 2014, 89, 1-10. [CrossRef]

7. Rico-Amoros, A.M.; Olcina-Cantos, J.; Sauri, D. Tourist land use patterns and water demand: Evidence from the Western Mediterranean. Land Use Policy 2009, 26, 493-501. [CrossRef]

8. World Economic Forum. Thirsty Energy: Water and Energy in the 21st Century; World Economic Forum: Geneva, Switzerland, 2009. 
9. Siems, R.; Sahin, O.; Talebpour, M.R.; Stewart, R.; Hopewell, M. Energy intensity of decentralised water supply systems utilised in addressing water shortages. In Proceedings of the 8th International Conference of the Eurpean Water Resources Association, Porto, Portugal, 26-29 June 2013.

10. Sanders, K.T.; Webber, M.E. Evaluating the energy consumed for water use in the United States. Environ. Res. Lett. 2012, 7, 034034. [CrossRef]

11. Sanjuan-Delmás, D.; Petit-Boix, A.; Gasol, C.M.; Farreny, R.; Villalba, G.; Suárez-Ojeda, M.E.; Gabarrell, X.; Josa, A.; Rieradevall, J. Environmental assessment of drinking water transport and distribution network use phase for small to medium-sized municipalities in Spain. J. Clean. Prod. 2015, 87, 573-582. [CrossRef]

12. Siddiqi, A.; Anadon, L.D. The water-energy nexus in Middle East and North Africa. Energy Policy 2011, 39 , 4529-4540. [CrossRef]

13. Lam, K.L.; Kenway, S.J.; Lant, P.A. Energy use for water provision in cities. J. Clean. Prod. 2017, 143, 699-709. [CrossRef]

14. Kenway, S.; Priestley, A.J.; Cook, S.; Seo, S.; Inman, M.; Gregory, A.; Hall, M. Water for a Healthy Country Flagship. In Energy use in the Provision and Consumption of Urban Water in Australia and New Zealand; CSIRO: Canberra, Australia, 2008; ISBN 978-0-643-09616-5.

15. Cohen, R.; Nelson, B.; Wolff, G. Energy down the Drain-The Hidden Costs of California's Water Supply; Natural Resources Defense Council, Pacific Institute: Oakland, CA, USA, 2004.

16. Perrone, D.; Murphy, J.; Hornberger, G.M. Gaining Perspective on the Water-Energy Nexus at the Community Scale. Environ. Sci. Technol. 2011, 45, 4228-4234. [CrossRef] [PubMed]

17. Plappally, A.K.; Lienhard, V.J.H. Energy requirements for water production, treatment, end use, reclamation, and disposal. Renew. Sustain. Energy Rev. 2012, 16, 4818-4848. [CrossRef]

18. Becken, S. Water equity-Contrasting tourism water use with that of the local community. Water Resour. Ind. 2014, 7-8, 9-22. [CrossRef]

19. Gössling, S.; Peeters, P.; Hall, C.M.; Ceron, J.-P.; Dubois, G.; Lehmann, L.V.; Scott, D. Tourism and water use: Supply, demand, and security. An international review. Tour. Manag. 2012, 33, 1-15. [CrossRef]

20. Katircioglu, S.T.; Feridun, M.; Kilinc, C. Estimating tourism-induced energy consumption and $\mathrm{CO}_{2}$ emissions: The case of Cyprus. Renew. Sustain. Energy Rev. 2014, 29, 634-640. [CrossRef]

21. Pombo, A.; Breceda, A.; Valdez Aragón, A. Desalinization and wastewater reuse as technological alternatives in an arid, tourism booming region of Mexico. Front. Norte 2008, 20, 191-216.

22. Rico, A.M.; Saurí, D.; Olcina, J.; Vera, J.F. Beyond Megaprojects? Water Alternatives for Mass Tourism in Coastal Mediterranean Spain. Water Resour. Manag. 2013, 27, 553-565. [CrossRef]

23. Angulo, A.; Atwi, M.; Barberán, R.; Mur, J. Economic analysis of the water demand in the hotels and restaurants sector: Shadow prices and elasticities. Water Resour. Res. 2014, 50, 6577-6591. [CrossRef]

24. Hall, C.M.; Amelung, B.; Cohen, S.; Eijgelaar, E.; Gössling, S.; Higham, J.; Leemans, R.; Peeters, P.; Ram, Y.; Scott, D.; et al. Denying bogus skepticism in climate change and tourism research. Tour. Manag. 2015, 47, 352-356. [CrossRef]

25. Michailidou, A.V.; Vlachokostas, C.; Moussiopoulos, N. Interactions between climate change and the tourism sector: Multiple-criteria decision analysis to assess mitigation and adaptation options in tourism areas. Tour. Manag. 2016, 55, 1-12. [CrossRef]

26. Zhang, L.; Gao, J. Exploring the effects of international tourism on China's economic growth, energy consumption and environmental pollution: Evidence from a regional panel analysis. Renew. Sustain. Energy Rev. 2016, 53, 225-234. [CrossRef]

27. Martínez-Ibarra, E. Climate, water and tourism: Causes and effects of droughts associated with urban development and tourism in Benidorm (Spain). Int. J. Biometeorol. 2015, 59, 487-501. [CrossRef] [PubMed]

28. Yoon, H. A Review on Water Energy Nexus and Directions for Future Studies: From supply to the demand end. Doc. Anal. Geogr. 2018, in press.

29. Teschner, N.; Garb, Y.; Paavola, J. The Role of Technology in Policy Dynamics: The Case of Desalination in Israel: The Case of Desalination in Israel. Environ. Policy Gov. 2013, 23, 91-103. [CrossRef]

30. Swyngedouw, E. Into the Sea: Desalination as Hydro-Social Fix in Spain. Ann. Assoc. Am. Geogr. 2013, 103, 261-270. [CrossRef]

31. March, H.; Saurí, D.; Rico-Amorós, A.M. The end of scarcity? Water desalination as the new cornucopia for Mediterranean Spain. J. Hydrol. 2014, 519, 2642-2651. [CrossRef] 
32. Gutierrez-Escolar, A.; Castillo-Martinez, A.; Gomez-Pulido, J.; Gutierrez-Martinez, J.-M.; Stapic, Z. A New System to Estimate and Reduce Electrical Energy Consumption of Domestic Hot Water in Spain. Energies 2014, 7, 6837-6855. [CrossRef]

33. Maas, C. Ontario's Water-Energy Nexus: Will We Find Ourselves in Hot Water ... or Tap into Opportunity? Project on Ecological Governance Water Sustainability Project; POLIS Project on Ecological Governance: Victoria, BC, Canada, 2010.

34. Parker, D.S.; Fairey, P. Estimating Daily Domestic Hot-Water Use in North American Homes. ASHRAE Trans. 2015, 121, 258.

35. Cheung, C.T.; Mui, K.W.; Wong, L.T. Energy efficiency of elevated water supply tanks for high-rise buildings. Appl. Energy 2013, 103, 685-691. [CrossRef]

36. Smith, K.; Liu, S.; Liu, Y.; Liu, Y.; Wu, Y. Reducing energy use for water supply to China's high-rises. Energy Build. 2017, 135, 119-127. [CrossRef]

37. Claver-Cortés, E.; Molina-Azorín, J.F.; Pereira-Moliner, J. Competitiveness in mass tourism. Ann. Tour. Res. 2007, 34, 727-745. [CrossRef]

38. Ivars Baidal, J.; Rodríguez Sánchez, I.; Vera Rebollo, J.F. The evolution of mass tourism destinations: New approaches beyond deterministic models in Benidorm (Spain). Tour. Manag. 2013, 34, $184-195$. [CrossRef]

39. INE. Indicadores Urbano 2017; Instituto Nacional de Estadística: Burgos, Spain, 2017.

40. HOSBEC. Hosbec Monitor 2017 Informe Coyuntura Tourística; HOSBEC: Benidorm, Spain, 2017.

41. City of Benidorm. Benidorm en cifra; Ayuntament de Benidorm: Benidorm, Spain, 2016.

42. Ediciones, L.V. Benidorm consume menos agua que hace 27 años pese a duplicar su población. La Vanguardia, 23 April 2014.

43. Iribas, J.M. Benidorm: Manual de uso. Via Arquit. 1997, 1, 66-73.

44. Cheng, C.-L. Study of the inter-relationship between water use and energy conservation for a building. Energy Build. 2002, 34, 261-266. [CrossRef]

45. Kaya, D.; Yagmur, E.A.; Yigit, K.S.; Kilic, F.C.; Eren, A.S.; Celik, C. Energy efficiency in pumps. Energy Convers. Manag. 2008, 49, 1662-1673. [CrossRef]

46. Informacion. La adjudicataria de la obras de la desaladora investigadas por amaño renuncia al contrato. Informacion, 7 August 2017.

47. Kempton, W. Residential hot water: A behaviorally-driven system. Energy 1988, 13, 107-114. [CrossRef]

48. Código Técnico de la Edificación (CTE-HE4). Sección HE 4 Contribución Solar Mínima de Agua Caliente Sanitaria. Available online: http:/ / www.terra.org/data/cteseccionhe4.pdf (accessed on 28 February 2018).

49. Mazón Martínez, T.; Delgado Laguna, E.; Hurtado Sánchez, J.A. Public Opinions of Stakeholders of Benidorm (Spain). Glob. Sci. Technol. Forum 2012, 1, 61-62.

50. Acceda a los servicios Catastrales. Available online: www.catastro.minhap.gob.es (accessed on 14 January 2016). (In Spanish)

51. EPRI (Electric Power Research Institute). Water \& Sustainability (Volume 4): US Electricity Consumption for Water Supply \& Treatment-The Next Half Century; EPRI: Palo Alto, CA, USA, 2002.

52. Lorenzo-Toja, Y.; Alfonsín, C.; Amores, M.J.; Aldea, X.; Marin, D.; Moreira, M.T.; Feijoo, G. Beyond the conventional life cycle inventory in wastewater treatment plants. Sci. Total Environ. 2016, 553, 71-82. [CrossRef] [PubMed]

53. Gil Olcina, A. Acondicionamiento, Rectificación y Regulación del Segura: Modificación de Lechos, Cuenca y Régimen Fluvial; Universidad de Alicante: Alicante, Spain, 2016; ISBN 978-84-9717-491-6.

54. Informacion. Callosa y Benidorm se enzarzan por los derechos del agua del Algar. Informacion, 24 May 2017.

55. Gil Olcina, A. Optimización de recursos hídricos y aromonización de sus usos: El Consortio de Aguas de la Marina Baja. Investig. Geográf. 2010, 51, 165-183. [CrossRef]

56. City of Benidorm. Acta de La Sesion Ordinaria Del Ayuntamiento de Ben Idorm, EL 27 de Diciembre de 2016; Ajuntament de Benidorm: Benidorm, Spain, 2016.

57. El Mundo. La provincia genera el 17\% de todo el agua reutilizada en Europa. El mundo, 17 April 2017.

(C) 2018 by the authors. Licensee MDPI, Basel, Switzerland. This article is an open access article distributed under the terms and conditions of the Creative Commons Attribution (CC BY) license (http:/ / creativecommons.org/licenses/by/4.0/). 